\title{
INDUSTRIALIZATION AND INFORMAL SECTOR IN SHAPING THE CITY: CASE STUDY AHMEDABAD-INDIA
}

\author{
Rully Damayanti \\ Department of Architecture, Faculty of Civil Engineering and Planning \\ Petra Christian University, Surabaya-INDONESIA \\ ASIA Fellow cohort-X \\ Email: rully@petra.ac.id
}

\begin{abstract}
Industrial activity is a prime determinant in shaping city size and growth opportunities especially in developing country, like India. Since industrialization started in Ahmedabad in 1950s, the city becomes larger and larger in terms of population and size. The growth of Ahmedabad city is highly affected by three urban generators on eastern part of the city. The research' aim is to identify and analyze the urban shape caused by the industrial activities and business activity that occupy public areas and streets. Since industrial activities became urban generators to change the use of land, from agriculture into developed land, it has affected the physical morphology of the urban areas. The research found that the existence of informal sector on these areas give an idea that industrial activity not only causes the change of land occupation, but also encourages the growth of informal commercial activity.
\end{abstract}

Keywords: Urban morphology, industrialization, informal sector.

\section{INTRODUCTION}

Ahmedabad is the largest city in Gujarat state and the seventh largest city in India. It has been a fast growing city since its inception in 1411. Industrialization in Ahmedabad was highly generated by the cotton mills industry in the year of 1950s. During the year of 1960's, there were three industrial estates developed on the eastern outskirt of the city: Vatva, Odhav and Naroda. The three estates are under management of GIDC on Gujarat state level (Gujarat Industrial Development Corporation). Since industrial activities of GIDC became urban generators to change the use of land, from agriculture into developed land, it has affected the physical morphology of the urban areas (Balchin, 2000). The surrounding area becomes more and more developed and is occupied for residential and commercial uses. Furthermore, due to the city development triggered by the increase in population, the area between the walled-city and the three industrial areas has experienced a great change.

Since industrial activities of industrial estates become urban generators to change the use of land, from agriculture to developed land, hence it also affected to the physical morphology of the urban areas. The research tries to analyze the growth of the city affected by the three urban generators located in eastern part of the city which are the industrial estates and commercial activities that occupies public land. Based on secondary data from related research, the development of the three estates could shift boundary of Municipal authority to further east. The changes are mostly caused by the existence of industrial estates on eastern part of Ahmedabad city. People that live or run their business nearby the estates, economically and socially take many advantages of their location, such as potential market of workers passing by, better infrastructure developed by the estates, and also better environment for family living.

\section{RESEARCH METHOD}

The research undertook mainly qualitative approach. The project used three types of data collection: document/literature study, land use survey, and a range of interviews. Document/literature study needs to be undertaken in order to give significant background of the project that industrial activity generates the growth of the city. Document study of current town planning and literature study of related project regarding Ahmedabad' city growth was used as secondary data in analyzing the city growth. Interview is an important technique to gain data which affects the impact of industrial activity of industrial estate related to the use of land.In order to identify accurately the land occupation along main streets of the three industrial estates, it is important to identify the current use of land, particularly the one used by informal business activity. The range and type of street vendor were defined by classifying each business according to types of retailer, goods of selling and degree of permanency. The identification 
was shown through map (will mark each location of vendor) and pictures. Survey was taken from November 2008 to May 2009 (early winter to end of summer) in the location of the case study.

\section{Ahmedabad' Urbanization}

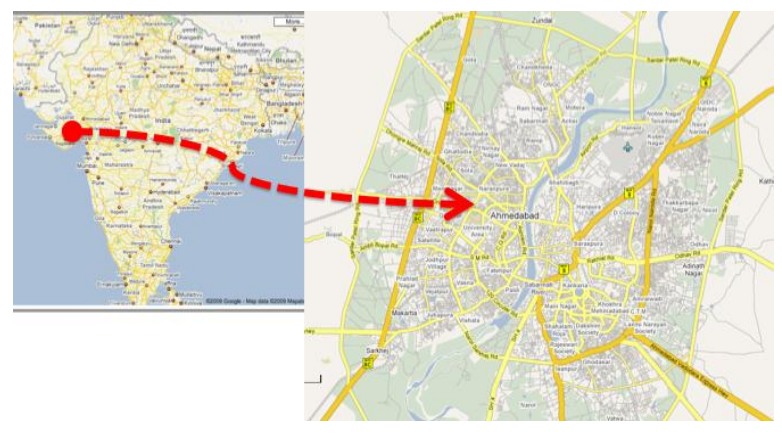

Figure 1. Location of Ahmedabad City

The development of Ahmedabad is strongly related to the rise of the indigenous industrial sector of cotton industry (Dijk, 2006). It grew in medieval times from a major trading centre for gold, silk and cotton (Dutta, 2000). The establishment of the first cotton mill in 1861 was the way in which this industry expanded over the years. In 1940s, the city was known as 'the Manchester of East' due to the famous textile industry (Dijk, 2006), which reflected the continuity of its distinct enterprise and business leadership (Dutta, 2000). In Ahmedabad, where native entrepreneurs created a textile industry that underlay the city' growth to the sixth largest in South Asia, there were 49 mills working in 1914 compared to 85 in Bombay (Heitzman, 2008).

The following statement is cited from paper by Shyam S. Dutta (2000), a historian who examined the Ahmedabad city:

"Unlike Bombay, Culcutta, Madras and Kanpur, Ahmedabad was not a creation of the British but a city which while remaining true to itself successfully adapted to the new industrial age carrying over commercial and industrial skills and patterns of traditional social organization. In no great city of India can the continuity of past and present be seen as clearly as in Ahmedabad"

Driven by the growth of textile industry reached its peak in the 1940s, the city attracted migration from around Gujarat and India. In the post-Independence period, the city witnessed not only diversification of its industrial base but also significant development of professional and technical institutions, such as the Physical Research Laboratory, the Indian Institute of
Management, and the Centre for Environmental Planning and Technology (Dutta, 2000).

In the late 1970s and 1980s, the textile industry has declined, resulting in the closure of more than half units and laying off about 60,000 workers. After 1990-1991, local economy has shown a revival. This is indicated by the reduction in the number of lowest income group and also an increase in regular workers. Compared to other cities in India (Bangalore, Pune and Hyderabad), Ahmedabad has the highest proportion of self-employed. It is a clear indication of the growing strength of the informal sector of the economy. The estimated share of the informal sector in the total of workforce in Ahmedabad increased from 50\% in 1981 to 64\% in 1991 (Dutta, 2000). Before 1980s, many factories were built on large estates in or around the centre city, and became centre of noise and pollution of its less infrastructure. The city suffered from traffic congestion and large number of slums. The old textile industries were no longer competitive, and new industries were located outside the centre of the city. In the year 1980s, the government did not allow polluting industries to locate in a radius of 20 $\mathrm{kms}$ around the city center (Dijk, 2006). Therefore, in 1968 the government developed three industrial estates under GIDC on the outskirt of the city.

Industrialization absorbs large number of workers both skilled and unskilled occupations. Urbanization is a likely consequence of industrialization in order to meet the needs of employers and employees. In the 1960s, almost 50\% of urban residents in developing countries were migrants attracted to jobs in industry (Williamson, 1995). According to Turnham (1990), there are two types of migrants: temporary migrants who come to seek employment in the informal sector, and permanent migrants who are seeking jobs in the formal sector but who temporarily may accept work in the informal sector, or be unemployed. An increasing population attracted to urban employment will produce the possibility of uncontrolled urban expansion, and a greater demand for urban infrastructure and urban land (Balchin, Isaac \& Chen, 2000). In brief, industrial development in developing countries is facing problems in adapting to the demands of urbanization. Currently, control of urban land and equal access to legal status is a major problem in many developing countries.

Population of Ahmedabad according to 2001 census was declared to be 3.5 million people. This number was only limited to the inside Ahmedabad municipal region (Wikipedia, 2009). Total population of Ahmedabad agglomeration is around 4.5 million: 4,518,240 (City Population, 2009). There are 886 females to every 1000 males. Ahmedabad has a 
literacy rate of $79.89 \%$, which is the highest in Gujarat. There are more than 30000 rural families living in Ahmedabad and 5,41\% of those are below poverty line. The city' population has increased in a major way following economic expansion and modernization. Ahmedabad becomes a centre for commerce and also government institutions and military base (Hindu, 2008).

\section{Characteristics of the Case Study}

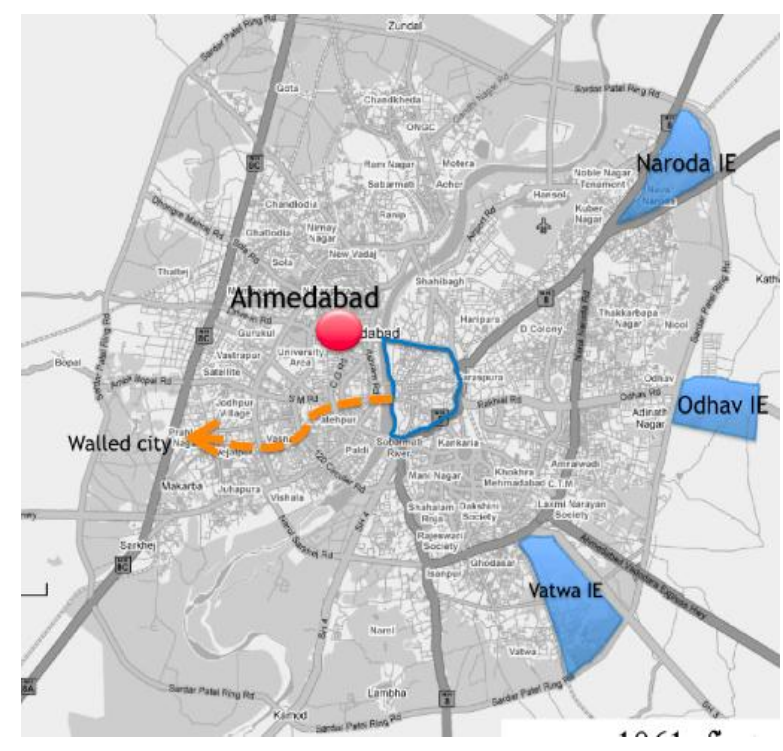

Figure 2. Location of the three industrial estates

There are three industrial estate under GIDC in Ahmedabad as the case study: Naroda Industrial Estate (NIE), Odhav Industrial Estate (OIE), and Vatva Industrial Estate (VIE).

Table 1. Characteristics of the Case Studies

\begin{tabular}{|c|c|c|c|c|}
\hline & & $\begin{array}{c}\text { NARODA } \\
\text { GIDC (NIE) }\end{array}$ & $\begin{array}{l}\text { ODHAV } \\
\text { GIDC (OIE) }\end{array}$ & $\begin{array}{c}\text { VATVA } \\
\text { GIDC (VIE) }\end{array}$ \\
\hline 1 & Year of establishment & 1968 & 1968 & 1968 \\
\hline 2 & Total area & 357 ha & 127 ha & 512 ha \\
\hline 3 & Number of plots & 689 & 491 & NA \\
\hline 4 & Numbers of sheds & 426 & 525 & NA \\
\hline 5 & $\begin{array}{l}\text { Distance from central } \\
\text { city (approximately) }\end{array}$ & $8 \mathrm{~km}$ & $4,5 \mathrm{~km}$ & $4,5 \mathrm{~km}$ \\
\hline 6 & $\begin{array}{l}\text { Number of company/ } \\
\text { factory }\end{array}$ & 660 & 1502 & 1187 \\
\hline
\end{tabular}

NIE is the oldest industrial estate in Gujarat, established in early 1968. It is located on the northeast of Ahmedabad city, occupies total area of 357 hectares. It has almost 660 factories for 689 plots, with total of 1300 workers. It also has supporting facilities such as school, post office, police office and public canteen. Since the establishment of the estate, the town has developed rapidly. Now, the estate becomes a part of Ahmedabad city. Naroda is approximately $8 \mathrm{kms}$ from Ahmedabad city, near the intersection of National Highway 59 and National Highway 8. According to 2001 census, total population in Naroda sub district was 44,554 excluding the agglomeration process (City Population, 2009). Naroda GIDC industrial estates host national and multi national corporations such as Reliance Industries Ltd., Pepsi Co, Ingersoll-Rand, Dresser, and various chemical and textile industries. Most major township project are coming up along with development of Ahmedabad-Vadodara expressway with Naroda being centre for development.

Population of Odhav sub district according to 2001 census was 21,474, excluding the agglomeration of the city (City Population 2009). OIE of GIDC was developed in 1968. On the north-east boundary, the estate is connected to Narol Naroda Road and Sardar Patel Ring Road. It is located around 4,5 kms from the central city. Outside the estate, along the Rakhial Road, many factories and small industries were developed. These industrial activities had existed before the industrial estate was developed. The reason for the choice of location for many factories and small industries along the road is the existence of Kharikat Canal (Varghese, 2009, interview). The canal lies from north to south and it functions as the main sewerage of many factories. In the case of NIE, final sewerage of water treatment plan (WTP) is through this canal to Sabarmati River.

VIE industrial estate was developed in the year 1968, which occupied 512 hectares of the land. It is located around 4,5 kms from the central city. This industrial estate is developed only several months earlier than two other estates' (Shah, 2008, interview). There are appproximately 1200 factories in the estate. Current condition of VIE is densely surrounded by commercial and housing uses. VIE is connected with the city and other city in Gujarat through State Highway-3, and connected as ring with other IEs through Narol Naroda Road on the North. VIE is the largest and oldest industrial estate of GIDC in Gujarat, consequently has the most effect to urban growth.

\section{Characteristics of Informal Business}

The research categorized the street vendor into local names and suffix 'wallas', which means 'vendor' (Jamdar, 2000). The categorization of types of retailers are: pathariwalas (display their products on the ground and stay permanently in a particular part of street or public spaces), lariwalas (own a 
mobile cart on which they vend goods and go around in their respective areas to sell), gallawalas-single (perform a single permanent element of the streetscape, set up a semi-permanent shop to sell, mostly food products), and gallawalas-shared (similar to gallawalas-single, but they shared space with formal shops).

Table 2. Characteristics of the Street Vendors

\begin{tabular}{|c|c|c|c|c|}
\hline No & Categorization & $\begin{array}{l}\text { NARODA } \\
\text { IE }\end{array}$ & $\begin{array}{c}\text { ODHAV } \\
\text { IE }\end{array}$ & $\begin{array}{c}\text { VATVA } \\
\text { IE }\end{array}$ \\
\hline \multirow[t]{5}{*}{1} & Types of retailers & & & \\
\hline & Pathariwalas & 4 & 5 & 1 \\
\hline & Lariwallas & 23 & 28 & 47 \\
\hline & Gallawalas (single) & 30 & 7 & 113 \\
\hline & Gallawalas (shared) & 19 & 3 & 16 \\
\hline \multirow[t]{4}{*}{2} & Permanency & & & \\
\hline & Permanent & 9 & 3 & 27 \\
\hline & Semi-permanent & 23 & 2 & 14 \\
\hline & Non-permanent & 44 & 38 & 136 \\
\hline \multirow[t]{8}{*}{3} & Goods for selling & & & \\
\hline & Chai/ coffee/ drinks & 24 & 11 & 33 \\
\hline & Food & 9 & 6 & 35 \\
\hline & Vegetables/ fruits & 3 & 1 & 11 \\
\hline & House wares & 15 & 7 & 1 \\
\hline & Sweets & 11 & 3 & 24 \\
\hline & Others & 10 & 15 & 19 \\
\hline & $\begin{array}{l}\text { Other combination of } \\
\text { goods for selling }\end{array}$ & 4 & - & 58 \\
\hline
\end{tabular}

The street vendors sell many types of goods; it can be categorized into: tea/coffee/chai/drinks, sweets/ mints/paan/cigarettes, snacks/food, vegetables/fruits, housewares, and other categories, such as cloths, bangles, sandals, painter, bike repair, phone/STD booth. To understand the type of building or hut where the business of street vendor has undertaken, the research was categorized into 3 types of permanency: permanent, semi-permanent, and non-permanent. These three categorizations are based on its building materials, and possibility to remove.

VIE has the most street vendors, namely 117 vendors, with highest land ratio compared to other case studies. In NIE and VIE, gallawalas-single were dominant; whereas in OIE, lariwallas is the most dominant one. Gallawalas-shared in NIE and VIE has significant number, which is almost $25 \%$ of the total vendors in that area. In OIE, more than $10 \%$ of the vendor is pathariwalas. Most of the vendors (more than $65 \%$ of total vendor) in the three case studies build their vendor using non-permanent material; such as wood, multiplex, and zinc. In the three IEs (NIE $11 \%$, OIE $7 \%$ and VIE $15 \%$ ) some vendors build their building base on permanent materials, such as bricks and cement. Semi-permanent materials in NIE and VIE has a significant number of more than $5 \%$.

There is a wide of variety of the goods sold, but most of them are food, drinks and other goods related to house-holds. In NIE, the two highest numbers are the sale of drinks and house-wares, in OIE are others (such as mobile phone accessories, clothes, and kidstoys) and chai seller, while in VIE the two highest number of goods sold are food and chai+sweets seller. Vegetables and fruits seller are also significantly sold in the three estates. The variety of goods sold in these three estates is similar, but in VIE most sellers sell more than one item, such as chaitsweets+ food, food+housewares, and also sweets+food.

\section{Nature of Linkages of Formal and Informal Sector}

The estate' management has provided affordable canteen and area for shops and market. During the survey, in the three estates, canteen has already been closed by the management, because only few workers wanted this facility (Shah, 2008, Varghese, 2009, interview). Most workers prefer food and drinks from the street vendor because of the taste and price. Street vendor sell their food/drink with less price than canteen with relatively tastier food. Area for shops or market inside the estate (absent for VIE) was built near the housing. Main costumer of the shops is the housing resident, which in current time, not only industrial estates workers lived in this housing but also other people who has no relation to the estate (case of NIE). Most proprietors live in villages near the industrial estates, and gets raw material from other villages as well (especially for fruits and vegetables). In average, most vendors have run their business inside the estate for more than 5 years and some of them started their business from the early development of the estate, and earned around 7500 rupees per month. There is no management regulation covering this kind of business, but there is only informal protection from factories (where they are located).

Most vendors open from 8 am to 9 pm daily, except for vendor near the main entrance of the three estates. Opening hours depend very much on the workers working hour. Some vendors' huts that are physically attached to the factory open for almost 24 hours. Vendors that operate near main entrance only open after working hours to provide food/ drink for labors and people passers-by. Street vendor that serves construction workers (especially in OIE and VIE) only open during working time, from 8 am to 4 pm.

The linkages between two sectors exist not only in term of target market of the street vendor, but also in terms of protection from the factory. Based on indepth interview with informal sector proprietor in NIE and VIE, especially vendor that run their business for generations, worker' factory has offered a/ some plot in front of the factory to their relatives who became 
street vendor proprietors. In this case, the worker works as the factory' security or others in the factory, which is later called as 'protector'. This man will arrange how long the vendor will occupy the land, in which area the hut will be built (vacant land, building setback, or hard shoulder), and how much the reward will be. The arrangement is only based on trust and no paper sign is required. The factory management knows this arrangement for some cases in order to provide cheap and nearest food/drink for their workers. The arrangement will work for ages and generations of the vendor proprietor (case study of NIE), even the factory' workers have changed for many times. It is difficult for the vendor to open a business informally inside formal area if they do not have this agreement. In other words, the factory provides food and drinks in reasonable price for the worker via allocation of street vendor inside or outside his area as long as they have the arrangement.

\section{Urban Morphology of Ahmedabad City}

In the early industrialization in Gujarat in 1960s, industrial activity was only clustered in several cities, for example Ahmedabad. The city became overcrowded and lack of effluent disposal sights. Furthermore, the land prices increased dramatically. These industries and mostly the new industries began looking for location sites outside the city limits, into the industrial estates which were established by the state in the rural parts of Gujarat. The state government under GIDC management developed some industrial estates in the outskirts, which are located at maximum of $10 \mathrm{kms}$ outside the city. The state government also gave incentives to industries to pursue land on those areas.

Industrialization in Ahmedabad which started booming in 1960s was triggered by cotton manufacturing. Many factories were developed inside the city and around the old city. Due to its pollution and traffic problem, in 1968, the government under GIDC management appointed packed areas of land on the eastern outskirt of the city. The industrial estates are: Naroda, Odhav and Vatva. After more than 40 years of development, the three industrial estates have generated the growth of its surrounding areas (Munshi, 2009, personal communication).

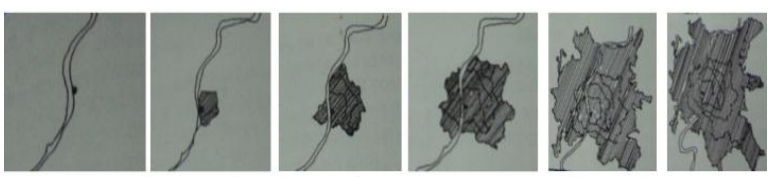

early development $1411 \rightarrow$ walled city $\rightarrow$ early industrialization $\rightarrow$ urbanization of $200 \mathrm{C}$

Source: The Vastu Shilpa Foundation, 2002.

Figure 3. Evolution of Ahmedabad City, from 1411 to 2000s
According to Shivnand Smanei (Sukhadia, 1997) in case of Ahmedabad city, in the 1980s, there was a law stating that $25 \mathrm{kms}$ outside the city could not be used for industries in order to protect agricultural land. Subsequently, new laws restructuring the process of acquiring land were enacted, making it easier to purchase land in what the government deemed outskirts, areas of low economic production and value. Incentives by the government were established to encourage industries to move away from central city, predominantly agricultural areas. As domino effects, land that is abandoned and not purchased by the state was slowly being polluted by the industries. The land gradually became infertile and was eventually sold to larger industrial estates (Sukadhia, 1997).

Referring to historical data and process of urbanization driven by industrialization, which is explained in the previous section, Ahmedabad' process of industrialization could be summarized into sections (time line) as follow:

- 1861: the first cotton mill was developed on the western side of the city

- 1940: since the city became famous as Manchester of East, it has attracted migration from outside Gujarat, hence the western side grew rapidly. Outside the walled city on eastern part,

- 1947: (post independence) eastern side of the city grew rapidly due to the development of some institutions and housing areas for middle income people

- 1968: development of three GIDC industrial estates on the eastern outskirt of the city (maximum of 8 km only)

- 1970-1980: textile industry has declined, many workers became unemployed

- 1980s: industrial activity developed on the outskirt of the city in radius of $20 \mathrm{~km}$ (government policy)

- 1986: the boundary of Ahmedabad Municipal Corporation (AMC) expanded to the three industrial estates

The boundary of Ahmedabad city has been expanded due to its increasing population and services. The development of the industrial estates (NIE, OIE, VIE) on eastern side significantly gave impact to the Ahmedabad Municipal Corporation (AMC) area. The growth of Ahmedabad city in this case is AMC area, could be seen in three different stages of growth. The growth could be defined in three types of urban shape of Ahmedabad city driven by industrialization. AMC has changed its boundary three times to respond to the city development and to meet the demand of its citizens. The three stages are: 


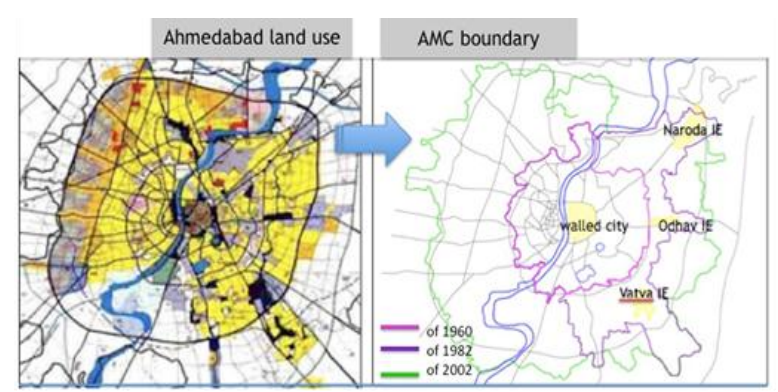

Source: AUDA 2009 - edited

Picture 4. Ahmedabad Land Use Regulation in 2009 and Shifted of AMC Boundary since 1960

1. In the year of 1960s, the economy of the city became stronger and cotton manufacturing activity became more and more developed around the walled city. The western side of the river was developed due to service development, city boundary was expanded to western side and outside walled city in the eastern part. This shape could be defined as the first changing of city' boundary generated by industrialization. Physical development of eastern and western side of the city is relatively balanced in shape; it is also driven by the development of bridges which connects both sides. Odhav, Naroda, and Vatva industrial estate are located outside the AMC boundary, since it is connected to dirty activity and inappropriate land use inside the city.

2. In 1982, the boundary of AMC was expanded only to the eastern side. The urban shape has protruding figurine of the three GIDC industrial estates, Naroda, Odhav, and Vatva, which are located on the eastern part of the city. The western boundary still remained the same. Naroda, Odhav and Vatva became part of AMC area due to the development of area in between the city and the industrial estates. The new urban shape at that time could be understood as a result of the change of land occupation development in between city centre and the industrial estates, from agriculture to developed land. It is also triggered by the development of ring roads and state/national highway around the city. Surrounding areas of the three estates became developed (radius of 1-2 kms from the estate) and they changed from agriculture into developed land, housing land occupation into commercial occupation. Some talukas (villages) that are located around the estates merged with the estate as one big area. From 1968 to 1986, the three estates mostly generated the growth of the surrounding areas, the three became urban generator of Ahmedabad city growth particularly on eastern part. After 1986, not only the industrial activity generated the areas, but also other service development, such as school, market, and some institutions.

3. In 2002, AMC expanded its area, both to eastern and western side of the city. There is no more protruding figurine of the three industrial estates. The three protruding shape has merged each other, hence become one solid shape with western boundary. The only boundary that remain the same is on the northern side, since it is connected to boundary of capital city; Gandhinagar. Issue of urban agglomeration became major concern of AMC to expand its area. It is mostly driven by the development of many ring roads and state/ national highway. Surrounding area of the estates has been appointed as commercial areas and light industrial areas.

\section{DISCUSSION AND CONCLUSION}

After studying the AMC land use, it can be concluded that the closer a city is to the three estates, the more developed is a city and vice versa. The shape of its urban areas on eastern side actually has three protruding shapes, in which each shape is the location of Naroda, Odhav and Vatva industrial estates. Areas between these protruding shape previously were vacant land and agricultural land. As predicted by AMC, these areas developed and grown in response to urban generator of the industrial estates, as long as the industrial activity operate. After more than 40 years of development, the three industrial estates generated the growth of its surrounding areas. Agriculture land has been changed into developed land, and use of land had also been changed, such from agriculture to housing, housing to commercial, and public land for private or commercial use. The industrialization process in those particular areas has triggered these changes. According to Balchin, Isaac and Chen (2000), industrialization always affected to people and urban shape. Population of that city became increased since the city offer many job related to industries.

Similar case is faced by most cities in developing countries, such as India and Indonesia: growth and development of the city, in terms of population and size, always followed by occupation of urban land illegally. The urban land occupation is mostly for illegal housing and illegal commercial activities in which some research called as informal city. Developing country adopted urban planning regulation from developed country, which ignored the existence of informal land occupation. Therefore, conflict between formal and informal sectors always 
occurs, such as government and street vendors. The existence of informal urban land occupation or informal city is a phenomenon of most city in developing countries.

The paper is a part of a bigger scenario of research to understand the growth of city triggered by location of industrial estates as urban generator to change the use of land both formal and informal. According to Balchin (2000), in urban area there are prime urban activities as urban generator that triggered the change of urban land value. The urban generator causes the change of use of land into higher value, such from agriculture land to residential, or residential to commercial use. Ahmedabad as an Indian city that has strong industrialization and cultural, the city grow particularly on the eastern part mostly driven by industrial activity of the three estates of GIDC. The boundary of Ahmedabad city was shifted three times follows the form of urban growth caused by developed land surrounding the industrial estates and also the land in between the estates and central city (walled city). Urban agglomeration is a significant issue for this case.

Ground data from street vendor in three estates of GIDC in Ahmedabad shows some important phenomena that there is a strong linkage between labors' and street vendors activity. The vendor provides daily drinks and foods (mainly) for the labor, such as chai, vegetables, fruits and lunch/ snack. This fact shows level of significance of the goods of sell of the street vendor. Even the estate management has provided facility for the workers (canteen and market), the workers prefer to buy they daily needs from the street vendor for reason of accessibility and price affordability. Market (for formal vendor) is more useful for resident of workers housing inside the estate (case of Naroda and Odhav) and also people passing by the main street of the estate (highway). The linkages between two sectors exist not only in term of target market of the street vendor, but in terms of protection from the factory. Behind location choice of the vendor, protection from the factory where the vendor built is equally important factor. Both factor should work equally since both sector (formal and informal) need each other; the formal need affordable and accessible food/drinks while informal sector always search for business location. In Ahmedabad, since the fall of textile industry, informal sector activity is very significant in numbers and give economic beneficiary to the city growth overall. Can be concluded here that flexibility factor of land occupancy for service facility to support workers activity is important, since it has high dependency with location of the factory and also with time of factory' operation.

As a final discussion, currently cities in most developing countries are facing fast development; both formally and informally. Planning and designing of the city are only respect to urban land occupancy formally or permanency for one single use. Needs to be considered by planner and architect that informal urban land occupancy always works parallel with formal occupancy. Therefore, the research highlighted the idea that the growth of city particularly in developing country should respect the existence of the informal sector. The existence should be a part of government' or municipal authority' strategy, by providing space and regulation for them. In Delhi for example, have a regulation for the vendor to have business license to run their business in a particular area. Thus, the city authority can control the growth as well as minimize the congestion caused by street vendors. For further study is how to accommodate the informal urban land whether as temporary users or shared urban space in particular uses.

\section{Acknowledgement}

The article based on research carried out in Ahmedabad, India from November 2008 to June 2009 under Fellowship provided by ASIA Fellows Award 2008 of Ford-Asian Scholarship Foundation (Ford-ASF). The research was taken under affiliation of Petra Christian University, Surabaya and Center of Environmental Planning and Technology (CEPT) in Ahmedabad- India.

\section{REFERENCE}

Balchin, P. I., David and Chen, Jean (2000). Urban Economics; a global perspective, New York, Palgrave, City population, www.citypopulation. de/India-Gujarat.html, 2009.

Dijk, Meine Pieter (2006). The Theory and Practice of Urban Management (e-book), UK, Edward Elgar Publishing Ltd.

Dutta, Shyam (2000). Partnership in urban development: a review of Ahmedabad's experience, http://eau.sagepub.com/cgi/content/abstract/12/1 /13, Environment and Urbanization.

Heitzman, James (2008). The City in South AsiaAsia's Great Cities (e-book), NY, Routledge.

Hindu (2008). The Ahmedabad yet to become mega city, www.hinduonnet.com/thehindu/2001/04/ 07/stories/0207000q.htm. 
Munshi, Neela (January 2009). (senior town planner AUDA), personal communication, Ahmedabad, 22.

Shah, K.H. (19 December 2008). (executive secretary Vatva Industries Association), personal communication, Ahmedabad.

Shah, Samir (8 January 2009). (executive secretary Odhav Industries Association), personal communication, Ahmedabad.

Sukadhia, Robin (1997). Industrialization and Economic Liberalization in Gujarat: the consequences for rural communities surrounding
Ahmedabad, www.astralaudio.com/india/Gujarat_ India_Industrialization.doc.

Varghese, Thelma (5 January 2009). (executive secretary Naroda Industries Association), personal communication, Ahmedabad.

Vastu Shilpa Foundation (2002). The Ahmedabad Chronicle: Imprints of a Millenium, Ahmedabad, Surya Offset.

Wikipedia (2009). Demographics and Culture of Ahmedabad, http://en.wikipedia.org/wiki/Ahmedabad\#Demographics. 